\title{
Hlutverk lækna í hagræðingu innan heilbrigðiskerfisins
}

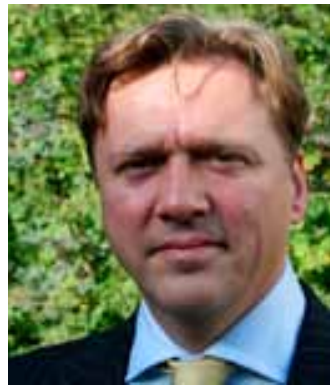

Sigurður Böðvarsson

sigurdbo@landspitali.is

Höfundur er lyf- og krabbameinslæknir á Landspítala og Læknasetrinu. MSc. i stjórnun heilbrigðispjónustu og formaður Læknafélags Reykjavíkur.

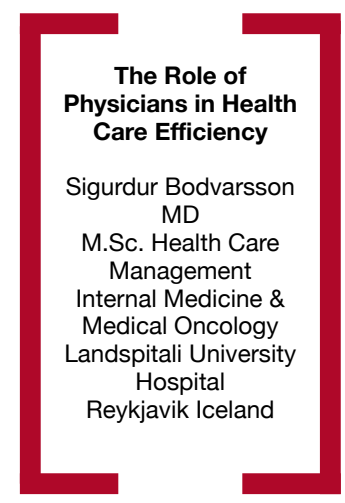

Á Læknadögum í janúar 2010 stóð ég fyrir málpingi um hlutverk lækna í hagræðingu innan heilbrigðiskerfisins. Frummælendur á pinginu voru sex góðir kollegar sem komu úr hinum ýmsu sérgreinum læknisfræðinnar. Petta voru pau Óskar Reykdalsson heilsugæslulæknir, Michael Clausen barnalæknir, Engilbert Sigurðsson geðlæknir, Helgi Sigurðsson krabbameinslæknir, Elísabet Benedikz bráðalæknir og Porbjörn Guðjónsson hjartalæknir. Pingið var vel sótt og nú hefur Læknablaðið ákveðið að gera pví góð skil með birtingu samantektar á framsögu hvers læknis í næstu tölublöðum. Óskar Reykdalsson ríður á vaðið að pessu sinni.

Heilbrigðispjónusta er um margt sérstæð pjónusta. Eftirspurn eftir henni er takmarkalaus en bjargir (resources) takmarkaðar. Pví er pað deginum ljósara að ekki er hægt að gera allt fyrir alla. Forgangsröðun á pví hvernig við ætlum að verja fjármunum til heilbrigðispjónustu er pví óhjákvæmileg og pví fyrr sem við gerum okkur grein fyrir pví, pví betra. Mörgum pykir ópægilegt að ræða forgangsröðun og á pað jafnt við um lækna og stjórnmálamenn. Hvorum hópnum um sig pykir forgangsröðun eiginlega vera einkamál hins. Ég er peirrar skoðunar að í pessu sem öðru eigi að fara saman pekking, reynsla og ábyrgð. Pví sé forgangsröðun verkefni lækna. Læknar verða í pessu tilliti að hafa í huga aldagömul siðalögmál sín og heit við sjúklinga um leið og peim ber að sýna ábyrgð gagnvart samfélagi, pað er priðja aðila sem stendur straum af kostnaði við pjónustuna að mestu leyti. Pessi hlutverk lækna eiga ekki að vera andstæð, heldur eiga hagsmunir sjúklinga og samfélags vel að geta farið saman og pað er lækna að gæta hagsmuna peirra beggja.

Upplýsingar eru stjórnsýslunni nauðsynlegar rétt eins og peningar fjármálakerfinu. Til að hægt sé að taka vitrænar ákvarðanir innan heilbrigðiskerfisins um ráðstöfun fjármuna verða pví að vera tiltækar upplýsingar um kostnað, afköst, framleiðni og svo framvegis. Kostnaðargreining er pví lykilorð innan allrar heilsuhagfræði og par með hagræðingar innan heilbrigðiskerfisins. Án hennar fálmum við í myrkri og tökum ákvarðanir á grunni tilfinninga sem ekki hafa alltaf vísað okkur fram á veg eins og dæmin sanna.

Innan heilsuhagfræðinnar hafa verið próuð og prófuð ýmis tæki og tól til að meta kostnað og ávinning af heilbrigðispjónustu. Eðlilega gengur leikurinn út á að fá sem mesta heilsu með sem minnstum tilkostnaði. Eitt af peim verkfærum sem hefur nýst hvað best í pessu efni er einingin "QALY", sem er í raun mælieining á lengd og gæði lífs sem hlýst af tiltekinni læknismeðferð við tilteknum sjúkdómi. Pannig er QALY 1,0 eitt ár við „fullkomna“ heilsu og 0,0 við dauða. Hinir ýmsu sjúkdómar og læknisfræðileg inngrip raða sér síðan parna inn á milli.

Í Bretlandi hefur National Institute for Health and Clinical Excellence (NICE) gjarnan miðað við pröskuldinn um 30.000 pund per QALY til að læknisfræðileg meðferð sé veitt við tilteknar aðstæður. Í Bandaríkjunum liggur talan meðal flestra tryggingafélaga í kringum $\$ 50.000$ per QALY.

Ég hefi pá trú að peir tímar séu liðnir par sem við læknar getum gert pað sem okkur dettur í hug hvað varðar meðferð sjúklinga okkar. Okkur ber að sýna ábyrgð bæði gagnvart sjúklingi og samfélagi og fara eftir sannreyndri læknisfræði hvað varðar alla meðferð. Önnur meðferð á heima í klínískum rannsóknum. Með pessu tryggjum við einnig að sjúklingar okkar fái sannreynda pjónustu sem samhæfir meðferð og dregur úr líkum á óhöppum.

Ég læet pessum pistli lokið með pví að vitna í góðan vin minn og kollega Pál Torfa Önundarson. Páll hefur ötullega bent á að pað er penni læknisins sem er dýrasta tækið innan heilbrigðiskerfisins. Læknar stjórna allri meðferð sjúklinga í heilbrigðiskerfinu frá vöggu til grafar, hvort heldur er um að ræða inn- eða útskriftir á sjúkrahúsum, rannsóknir, meðferðir, lyfjaávísanir eða eftirlit. Höfum pað í huga. Okkar er pekkingin, ábyrgðin og valdið. 